\title{
Potoczki Zoltán: Jövedéki jogintézmények egykor és most
}

\begin{abstract}
Absztrakt
A jövedéki adóztatás szövevényes múltra tekint vissza. A mai szabályozás gyökerei a 19. századi jövedékek, illetve más, fogyasztási típusú adók formájában mutatkoztak meg: A különbözö állami monopóliumok között megtaláljuk a lottó-, illetve sóárusitás, valamint az italmérés jogát, majd pedig Amerika felfedezését követöen megjelenik a dohányjövedék is. Jelen tanulmány azon tézisen alapul, mely szerint a mai jövedéki jogintézmények a 19. századi jövedéki jogintézményeken és az ahhoz kapcsolódó szabályozáson alapul.
\end{abstract}

\section{Abstract}

The excise tax has a convoluted history. The current regulation roots in the $19^{\text {th }}$ centuries's excise duties and other consumption taxes like trade of lottery, salt and spirits among the various state monopolies, and, after the discovery of America, the tobacco excise duty appears, too. This study is based on the thesis that today's excise law institutions are based on 19th century excise law institutions and related regulations.

$* * *$

\section{Bevezetés}

„Az egyedáruság által az állam a gazdasági müfolyamat bizonyos pontján, legyen az a termelés, a forgalom vagy a fogyasztás, az árképzést megragadja és ezáltal jövedelmet biztosit a maga számára. Pénzügyileg az egyedáruságok különösen nagy jövedelmek biztositása által nyújtanak elönyöket, bár másfelöl a fogyasztásra és termelésre károsan hathatnak.”"471 „A kormány néha több egyedáruságok birtokában vagyon: ezen egyedáruságok vagy bizonyos portékákkali kizáró kereskedést, vagy azoknak gyártását tárgyalják, czéljok pedig az, hogy a polgároktól illy formán indirect uton, és pedig könnyen adó bevétethessék..."472

A jelenlegi jövedéki szabályozásban meghatározott adótárgyak többsége évszázadok óta az állami bevételek alapjául szolgál. Az e körbe tartozó különböző bevételi források voltak a történelem során a regálé, az egyedáruság, a fogyasztási adó. Első megjelenési formájuk a regálék (királyi haszonvétek) voltak, amelyek kezdetben az állam legfontosabb bevételi forrásait képezték ${ }^{473}$. A XVI. századtól már megkülönböztették egyrészt azokat a királyi kiváltságokat, amelyek a főhatalom elidegeníthetetlen részei (regália major), mint a pénzverés, sorsjáték (lottó), posta, lőporgyártás, másrészt a magánjogi jellegzetességeket mutató, átruházható

\footnotetext{
${ }^{471}$ ÁLDÁSSY Antal - ÁBRÁNYI Kornél - ACZÉL Károly - ÁGOSTON József (szerk.): Pallas nagy lexikona. Budapest, Pallas Irodalmi és Nyomdai Részvénytársaság, 1895, p. 982.

${ }^{472}$ KARVASSY Ágoston: Politikai tudományok. III. kötet: A fináncztudomány. Györ, 1844. p. 28.

${ }^{473}$ MAGASVÁRI Adrienn: Vám- és adószedők a magyar pénzügyi igazgatásban az államalapitástól a kiegyezésig.

RENDVÉDELEM TÖRTÉNETI FÜZETEK, 25. évf, 43-44-45-46. sz., 2016, p. 39.
} 
haszonvételeket (regália minor), mint az italmérési, vásártartási, malomüzemeltetési jogokat. Magyarországon az Árpád-házi királyok uralkodása alatt a só kitermelése és forgalomba hozatala, illetve az ezüst bányászata és a pénzverés volt a legfontosabb. Az állami monopóliumot egyes termékeknél az előállítást, másoknál az értékesítést illetően tartották fenn. Nem volt azonban példa nélküli a teljes gyártási és eladási folyamat monopolizálása sem, példa erre a magyar sótermelés és árusítás. ${ }^{474}$

A jövedék fogalma alatt a régi magyar jogrendben az államnak a jövedéki termék előállításához, forgalomba hozatalához kapcsolódó kizárólagossági jogát értették, mely egyfajta egyedárusági jogot és az abból származó költségvetési bevételt biztosított az adott állam számára. Az állam a bevételeinek nagyfokú biztosítása érdekében rendkívül szigorú követelményrendszert alakított ki a jövedéki termékek vonatkozásában, melyek iránt viszonylag állandó, biztos kereslet alakult ki, és magas adótartalmat hordozott magában. Ezen termékek szigorú hatósági felügyelet alatt álltak, $\mathrm{s}$ állnak ma is: zárt pályákon történt a termelésük, gyártásuk, tárolásuk, szállításuk és a forgalmazásuk pedig komoly hatósági kontroll alatt állt. A szigorú hatósági kontroll abban is testet öltött, hogy egyes jövedéki termékek elöállítására kvótákat állapítottak meg és egyes áruk tekintetében konkrét elöírásokat tartalmaztak arra vonatkozóan, hogy azokat kik, milyen célra állíthatják elö, illetve azok mily' módon kerülhetnek forgalomba. A jövedéki termékekkel visszaélőket a korabeli jog szigorú szankciókkal illette. A jövedéki kihágások ügyében 1867-ig pénzügyi hatóságok, majd jövedéki törvényszékek és pénzügyi törvényszékek ítélkeztek. Az 1883. évi XLIV tc. - jövedéki bírói jogkörrel - külön királyi törvényszéket ruházott fel hatáskörrel.

Az 1850-es évektől kezdődően, nagyrészt a közjogi rendszer megváltozásának következtében, létrejött az a szisztéma, amely a második világháború végéig müködött. Megkülönböztették a jövedékeket (állami egyedáruság vagy monopólium) és a fogyasztási adókat. A jövedékek közé tartozott például a dohányjövedék, a sójövedék, a pénzverési és bankjegy-kibocsátási jövedék, az italmérési jövedék és a vámjövedék. A fogyasztási adók közé például a söradó, ásványolajadó és a cukoradó tartozott. A jövedék az állami monopóliumot jelenti, tehát azt, hogy egy meghatározott tevékenység gyakorlására kizárólag az állam jogosult, azonban e tevékenység gyakorlására esetenként engedélyt adhat magánvállalkozás számára: például a bányajog alapján az ásványolaj kitermelésére. Ma ezt koncesszióba adásnak neveznénk. ${ }^{475} \mathrm{~A}$ II. világháborút követően a szocialista tervutasításos rendszerben a jövedéki szabályozás elhalt. A rendszerváltás előtti évtizedben újra megjelentek a fogyasztási adók, majd a rendszerváltás hajnalán „újraéledt” a magyar jövedéki szabályozás is, amely jellegét, jogintézményeit tekintve a szocializmus előtti szabályanyagon alapul.

Az alábbi történeti vázlat - terjedelmi okok miatt a teljesség igénye nélkül - a komparatisztika módszertanának segítségével a jövedéki szabályozás kiegyezéskorabeli jellegzetességeit, egyes jövedéki jogintézményeit veti össze a jelenlegi jövedéki szabályozás jellegzetességeivel, jogintézményeivel. A tanulmány fő hipotézise az, hogy a jelenlegi és az egykori szabályozás lényegi elemei között nincs releváns különbség, vagyis a mai szabályozás a 19. század végi, ill. 20. század eleji jövedéki szabályozás alapjaiból merítkezik. Mindebből következően a hatályos hazai jövedéki szabályanyagról megállapítható, hogy szerves összefüggést mutat az egykori szabályanyaggal, annak modernizált, elektronizált, továbbfejlesztett változatát képezi.

\footnotetext{
${ }^{474}$ SIMON István (szerk.): Pénzügyi jog II. Budapest, Osiris kiadó, 2012, p. 224.

${ }^{475}$ Uo.
} 


\section{Egyedáruság-engedélyezési eljárás}

\subsection{Dohányegyedáruság}

Az 1867. évi kiegyezést követően a magyar minisztériumok - és így a Magyar Királyi Pénzügyminisztérium ${ }^{476}$ - visszaállításával együtt a dohány egyedáruság is önálló lett, amelynek következtében létrejött a magyar dohányjövedék. A dohány jövedékisége teljes egyedáruságot jelentett, vagyis azt, hogy mind a nyers dohány, mind pedig a dohánygyártmányok felett kizárólagos rendelkezési jog illette meg az államot. Ezen kizárólagos jog folytán senkinek nem volt szabad az illetékes hatóság engedélye nélkül dohányt termelni, dohányt tiltott módon készíteni, felhasználni, vagy forgalomba hozni, illetve dohányt bármely célra - akár csak átszállítás végett is - külföldröl behozni. ${ }^{477}$ A jogi szabályozás rendkívül szigorú engedélyezési, kontroll-, illetve szankciórendszer útján került érvényesítésre: A termelés megkezdésére a pénzügyi hatóság adott engedélyt azon személyek számára, akik eleget tettek a szigorú személyi, tárgyi, garanciális feltételeknek, valamint korlátozó rendelkezéseknek. ${ }^{478}$ Ilyen engedélyezési feltétel volt például az, hogy termeszteni „dugárusok,” azaz csempészet miatt jogerősen elítélt személyek nem voltak jogosultak. Fő szabály szerint a termesztésre azokat a földterületeket preferálta a dohánybeváltó felügyelőség, ahol az engedélyezés előtt már dohánytermesztés folyt ${ }^{479}$. Mindemellett előírták a megfelelő (talaj)minőségi feltételek meglétét is. A dohány termesztése a kincstár számára - vagy kiviteli céllal, külön engedély mellett - történt, így ahhoz beszolgáltatási kötelezettség társult. A dohánytermesztés éves határideje az adott tárgyév június 30-ig tartott. Az engedélyesek a dohánynövény elökészítését (szárítását, összekötözését) követően kötelesek voltak a termesztett dohánynövényt beszolgáltatni a dohánybeváltási bizottságokhoz.

A dohány élvezeti cikként történő feldolgozása is kizárólagos állami monopólium tárgyát képezte. Tilos volt tehát a dohánynövényt akár ipari, akár magáncéllal feldolgozni, illetőleg abból bármilyen dohánygyártmányt előállítani. Tilos volt továbbá az illetékes hatóság engedélye nélkül dohánygyártmány előállítására alkalmas eszközöket - akár belföldröl, akár külföldröl - beszerezni, birtokolni, készíteni. Tilos volt mindemellett a dohánygyártmányok csomagolására, felszerelésére (kiszerelésére) és a szivarkák készítésére használt nyomtatványok és hüvelyek külföldről való beszerzése, valamint szivarkáknak ellentételezés fejében, vagy bármely más módon történő készítése, készíttetése is. ${ }^{480}$

A dohány nagy- és kiskereskedelem kizárólag az illetékes pénzügyi hatóság engedélye birtokában, az engedélyben foglalt szigorú követelmények maradéktalan betartása mellett történhetett. Az engedély megléte esetén az értékesítés joga kizárólag az engedélyben meghatározott területre és csupán az engedélyben felsorolt termékkör

\footnotetext{
${ }^{476}$ SzABÓ Andrea: A pénzügyi igazgatás szervezete és képzési rendszere a kiegyezéstől az I. világháború végéig. In: CZENE-POLGÁR Viktória - ZsÁMBOKINÉ FICSKOVSZKY Ágnes (szerk.): Mérföldkövek az adóés vámigazgatás történetéből. Magyar Rendészettudományi Társaság Vám és Pénzügyőri Tagozata. Budapest, 2017. p. 125. és SzABÓ Andrea: A pénzügyi igazgatás szervezeti keretei egykor és most a rendészeti feladatok tükrében. In: GAÁL Gyula - HAUTZINGER Zoltán (szerk.): Szent Lászlótól a modernkori magyar rendészettudományig. Pécs, 2017. p. 351.

477 TAKÁCS György: Közadózásunk (jelen esetben pénzügyi jogi ismeretek, magyarázatok). Magyar Magánalkalmazottak Szabad Szakszervezetének Kiadása Bp. 1946. p. 176.

${ }^{478}$ TAKÁCS: i. m. pp. 176-177.

${ }^{479}$ PAPP Antal: Dohányjövedék. Toldy Lajos Könyvkereskedő Bizománya. Budapest, 1907., p. 7.

480 TAKÁCS: i. m. p. 178.
} 
forgalmazására korlátozódott. A dohányárus a kincstár bizományosának számított és tevékenysége során a szabályoknak és utasításoknak minden tekintetben megfelelni tartozott. A bizományosi jogviszonyt mindkét fél 3 hónapos felmondási idővel mondhatta fel. A pénzügyi hatóság által felmondott bizományosi szerződés esetén kártalanítás nem járt. Az üzlet vezetését kizárólag az engedélyben megnevezett személy végezhette, bérbe adni, átengedni, vagy másra rábizni nem lehetett. A kiskereskedelmi egységek, trafikok mellett a korabeli jogi szabályozás - a mai szabályozáshoz képest liberálisabb módon - lehetőséget biztosított a szálláshelyek és vendéglátóipari egységek számára is arra, hogy dohányárut értékesítsenek: a szállodák, vendéglők és kávéházak üzemeltetői engedély birtokában az erre kijelölt helyen és az elöre bejelentett értékesítéssel megbízott személyek útján gyakorolhatták a fogyasztók dohánytermékekkel történő kiszolgálását. ${ }^{481}$

A korabeli dohánykereskedők típusai voltak a teljes értékesitési jogositvánnyal rendelkezö árusok (mai értelemben nagykereskedők); továbbá a mai importőrnek megfelelő kereskedők, akik más országokból szerezhettek be dohányárut; valamint az ún. „,kizárólagos kisárusok”, vagyis a mai értelemben vett kiskereskedők, akik általában a belföldön forgalomban lévő dohánytermékek forgalmazására voltak jogosultak. (Kivételes esetekben - külön engedély birtokában - értékesíthettek különleges fajtájú, márkájú dohánytermékeket is). Az ún. „korlátlan kisárusok” fo profilja az volt, hogy más termékeket árultak ( $\mathrm{pl}$ : szatócsüzletek, papírkereskedők), de engedély birtokában mellette - járulékos jelleggel - kizárólag fogyasztók számára, azaz kiskereskedelmi céllal értékesíthettek dohánytermékeket is. Az utolsó kategóriába az un. „korlátolt kisárusok", vagyis a korábban már említett vendéglátók tartoztak.

\subsection{Italmérési jövedék}

„A szeszes italok kimérése és kis mértékben való elárusitása fölött a kizárólagos rendelkezési jog az állam részére tartatik fenn. Ezen jog folytán korcsmákat nyitni vagy a már meglevóket fentartani csak az állam engedélye mellett szabad......Az italmérések számának korlátozása tekintetében a törvény kimondja, hogy a kis mértékben való elárusitások száma nem korlátozható, ellenben a kimérési engedélyek száma az állandó és hullámzó lakosság szükségletére, a közlekedési, forgalmi, társadalmi és gazdasági viszonyokra való tekintettel állapítandó meg; a szükség követelményeinek megfelelöleg a tényleg meglevö kimérések száma apasztható. Az engedély megtagadandó, s ha már kiadatott, visszavonandó attól, ki ellen oly tények merülnek fel, melyekböl arra lehet következtetni, hogy az engedélyt tiltott játék, orgazdaság, uzsora vagy erkölcstelenség elömozditására és terjesztésére használja fel. A kimérésre és kis mértékben való eladásra engedélylyel birók kétféle szolgáltatást tartoznak teljesiteni: állandó összegben megállapitandó évi italmérési illetéket $s$ a kimért szeszes italok neméhez és mennyiségéhez mért italmérési adót tartoznak fizetni. ",482

Az 1888. évi XXXV. törvénycikkel bevezetett italmérési jövedék - kezdetben az állam szeszesital kimérésének és kismértékben való árusításának jogát szabályozta: A monopólium tehát ekkor még csupán az alkoholtermék kiskereskedelmére korlátozódott. A szabályozás a borra és gyümölcsborra, valamint a sörre és égetett

\footnotetext{
${ }^{481}$ TAKÁCS: i. m. p. 179.

482 Pallas Nagylexikona https://www.arcanum.hu/hu/online-kiadvanyok/Lexikonok-a-pallas-nagylexikona-2/h-B866/italmeresi-jovedek-D925/ (Letöltés ideje: 2019. augusztus 17.)
} 
szeszek kimérésére és kismértékben történő eladására terjedt ki. ${ }^{483} \mathrm{Az}$ engedélyt az írásos kérelemre a királyi pénzügyigazgatóság adta ki, méghozzá rendkívül szigorú követelmények felállítása mellett: a ,teljes korú teljesen megbízható, feddhetetlen magyar állampolgár részére." Jogi személy esetében az előbbi feltételeknek a boltvezető kellett, hogy megfeleljen, valamint nem volt adható olyannak engedély, aki ,azt tiltott játék, orgazdaság, uzsora és erkölcstelenség elömozdítására és terjesztésére" használta fel.

A korabeli szabályozás értelmében érvényesítendő követelmény volt az, hogy a kimérés helyszíne megfelelő távolságra legyen az iskolától, kórháztól és templomtól, hogy könnyen megközelíthető legyen a hatóságok számára, és hogy a közegészségügyi előírásoknak megfeleljen. Az engedély a feltételek nem teljesítése, megszegése esetén visszavonásra került. Mindemellett az engedély lehetőséget biztosított - a mai szóhasználattal élve - az üzleti tevékenység „kitelepülésére” is (alkalmi rendezvények, piacok, vásárok esetén). Az egyedáruság megváltásáért egyrészt kellett fizetni italmérési illetéket, másodsorban italmérési adót a kimért italok mennyisége és fajtája szerint. A fizetendő adó differenciált volt aszerint, hogy az engedélyes milyen vállalkozást üzemeltetett (bortermelő, „kávés”, cukrász), és hogy milyen osztályba tartozott. Az illeték mértékét a pénzügyigazgatóság határozta meg háromévente, melynek döntése ellen fellebbezni lehetett. ${ }^{484}$

1899. évben új szabályozás lépett életbe, ami nem csupán a kimérést, és a kismértékben történő eladást, de az égetett szesz nagyban történő eladását (nagykereskedelmét) is engedélyhez kötötte. Fontos, új elem volt tehát a desztillált szesz (mai szóhasználattal élve: alkoholtermék) nagykereskedelme vonatkozásában az állami monopólium kiterjesztése. Nem kaptak engedélyt a mai értelemben vett közszféra dolgozói, de a lelkészek és a szülésznők sem. A törvény mindemellett deklarálta a jövedéki hatósági felügyelet alkalmazásának kötelezettségét is: „az italmérési és italárusítási üzletek és vállalatok jövedéki felügyelet alatt állnak." ${ }^{485}$

Az italmérési jövedék 1938-tól teljeskörüvé vált: a szeszegyedáruság értelmében az ország területére behozott, vagy ott előállított valamennyi alkoholtermék (szesz) az állam kizárólagos rendelkezése alatt állt mindaddig, amíg azt a szesz egyedárusági igazgatóság akár a felhasználási cél meghatározásával, akár anélkül szabadforgalomba nem bocsátotta. Innentől kezdve a kis-és nagykereskedelem mellett az alkoholtermék belföldi elóállítása, továbbá - ma szóhasználattal élve exportja-importja is engedélyköteles volt. Mindemellett - a sörgyártás kivételével - tulajdonképpen a szesz alapanyag elöállítás is engedélyköteles volt, illetve hatósági kontroll alatt állt: bármely más célból keményítőből, illetve keményítőt tartalmazó anyagból, illetőleg cukorból, vagy cukrot tartalmazó anyagból - kivéve a gyümölcsöt - cefrét készíteni és erjeszteni kizárólag a pénzügyminiszter engedélyével volt szabad. A szeszfőzde vállalkozója köteles volt az általa elöállított szeszt az időközönként megállapított beváltási árért a szeszegyedárusági igazgatóság rendelkezésére bocsátani. Az igazgatóság a rendelkezésre bocsátott szeszmennyiséget egyedárusági eladási áron, vagy pedig kedvezményes egyedárusági eladási áron bocsátotta szabadforgalomba. A beváltási és az eladási ár közti különbözet volt az un. egyedárusági különbözet. ${ }^{486}$

\footnotetext{
${ }^{483}$ SIMON Zoltán - POZSGAI Zoltán - KIS Judit - BoROS Sándor: Jövedéki alapok I. VIVA Média Bp. 2006. pp. 17-18.

${ }^{484}$ SIMON - POZSGAI - KIS - BOROS: i. m. pp. 17-18.

${ }^{485}$ Lásd bővebben: 1899 . évi XXXVI. törvényczikk

${ }^{486}$ TAKÁCS: i. m. p. 168.
} 
A korszakra jellemző jövedéki szabályozás célját, lényegi elemeit, a jogalkotó szándékát - melyben a társadalmi-gazdasági összefüggések is kirajzolódnak - az alábbi idézetben található szövegrész szemlélteti a legjobban: „A bor, ser, 's szeszes italok viszonylagos nélkölözhetöségök 's mégis nagy mérvbeni használatuknál fogva igen alkalmas accisa ${ }^{487}$-adótárgyat képeznek, mely még azon elönnyel is jár, hogy igen jól simul különbözö minöségi-fokai szerint a különbözö osztályok vagyoni ereje és adózási képességéhez, 's hogy az ez italszerekre vetett adók erkölcsi tekintetben is jóhatásuak lehetnek, a mennyiben az embereket túlságos használásától a szeszes italoknak elvonják. Ez áll az italszerekre vetett adók tekintetében általában. "488

\section{3. Ásványolaj egyedáruság}

Ásványolajtermékek vonatkozásában az a személy, aki ásványolaj finomítói tevékenységet kívánt végezni, a tevékenysége tervezett megkezdése előtt legalább négy héttel a területileg illetékes pénzügyi igazgatóságnak köteles volt azt bejelenteni. Az írásbeli bejelentés megtételekor két példányban csatolni kellett az üzlethelyiség/gyáregység alaprajzát, az ásványolajkészletek, mérőeszközök, edények és tartók jegyzékét, továbbá a müszaki eljárás leírását, az üzleti rend nap- és óra szerint való bejelentését és az üzletvezető nevét. A pénzügyigazgatóság ezt követően elrendelte az ásványolajfinomító-üzem hitelesítését, melynek keretei közt az üzlethelyiségek, edények, mérőeszközök, tartók és ásványolaj-készletek megvizsgálásra, szemrevételezésre kerültek. A vizsgálat eredményéről a pénzügyi közeg jegyzőkönyvet, úgynevezett lelet-jegyzökönyvet vett fel, melyben azok az útvonalak is feltüntetésre kerültek, melyeken az engedélyezett módon az előállított ásványolajtermékek elszállíthatóak voltak. ${ }^{489}$

\section{Jövedéki jogintézmények}

\subsection{Adóügyi jelzések (adójegy) ${ }^{490}$ alkalmazása}

Az adólerovás módja az adójegy (banderoll) ${ }^{491}$ alkalmazása volt. A részletes leírása szerint kilenc centiméter hosszú, másfél centiméter széles, vízjeles, rajzzal ellátott papírszelet, melyet az alkalmazása során úgy kellett a dobozokra, illetve a csomagokra felhelyezni, hogy annak felszakítása nélkül a szivarhüvelyt, vagy papírt sérülésmentesen ne lehessen kivenni. Az adójegy érvényesítése a vállalkozó pecsétlenyomatának alkalmazásával történt, vagyis az adójegyet „értéktelenítési jellel” kellett ellátni. A jellel ellátott adójegy alapján tudta azonosítani a korabeli pénzügyi hatóság a felhasznált adójeggyel ellátott dohánygyártmányért felelős vállalkozás kilétét.

\footnotetext{
487 accisa $=$ jövedék, állami jövedelem, angolul: excise

${ }^{488}$ KaUtz Gyula: Nemzetgazdaság és Pénzügytan. Kiadja: Heckenast Gusztáv Pest, 1863. p. 640.

${ }^{489}$ EXNER Kornél: Magyar Pénzügyi Jog. Atheneum Irodai és Nyomdaipari Részvénytársulat kiadása, Budapest, 1910. p. 373.

${ }^{490}$ Az adójegy fó funkciója - a mai szabályozáshoz hasonló módon - abban állt, hogy a jövedéki termékre történő felragasztással egyfelöl tanúsítja, hogy az adott termék a hatályos jogszabályok szerint került szabadforgalomba (akár belföldi elöállítás, vagy import útján), illetőleg mindemellett azt is igazolja, hogy a konkrét termék vonatkozásában a hatályos adók maradéktalanul megfizetésre kerültek.

${ }^{491}$ TAKÁCS: i. m. p. 151.
} 


\subsection{Adómentes felhasználás}

A mai adómentes felhasználó megfelelője ebben az időszakban az un:,Kedvezményes egyedárusági áron szerzett szesz felhasználója” volt. Az egyedárusági árból a pénzügyminiszter 7,5\% engedményt engedélyezhetett az alábbi célokra: bor és must szesztartalmának emelésére, ecetgyártási célra, égetési, tisztítási, ipari, illetve tudományos célokra, továbbá pipere- és kozmetikai célokra, valamint gyógyászati készítmények (tinktúrák, fertőtlenítő szerek...stb.) készítése céljából. ${ }^{492}$ Ezek a kedvezményes adózású felhasználási célok gyakorlatilag megfelelnek napjaink jövedéki szabályozásában az adómentes felhasználás szabályainak. „Kedvezményes egyedárusági eladási áron szesz csak a pénzügyminiszter engedélyével szerezhetö be. Az ilyen módon elöállított szeszt elöállitó, finomitó, viztelenitö vállalat, illetöleg szeszszabadraktár üzemi helyiségéböl való elszállitás elött meghatározott módon emberi élvezetre alkalmatlanná kell tenni (denaturálni). A kedvezményes egyedárusági eladási áron beszerzett szeszt kizárólag arra a célra lehet felhasználni, amely célra azt kiutalták. ${ }^{493}$ Ebben az időszakban a legtipikusabb adómentes/kedvezményes adózású alkohol-felhasználási mód az ecetgyártás volt: „Szesznek ecetgyártás céljára kedvezményes egyedárusági beszerzésére és felhasználására vonatkozó pénzügyminiszteri engedélyek határozatlan idöre szólnak és bármikor visszavonhatóak, illetöleg módosithatóak. Az ecetgyártás céljára termelési időszakonkint kiutalt szesz mennyiségét a pénzügyminiszter állapítja meg az ecetgyári érdekeltség meghallgatása után. " "494

\subsection{Adóraktárak}

„Szeszszabadraktár létesitésére csak olyan vállalkozó kaphat engedélyt, aki évenkint legalább kétezer hektoliter szeszt forgalmaz. Természetes követelmény az, hogy a tárolt szeszárukból a meg nem adózottakat (adóval terhelteket) a szabadforgalomba bocsátottaktól elkülönítetten kell kezelni." ${ }^{495}$ A korabeli szeszüzem (alkoholtermékadóraktár) típusok az alábbiak voltak: egyedárusági szeszfőzde; mezőgazdasági szeszfőzde; ipari szeszfözde; bor- és gyümölcs szeszfőzde. ${ }^{496}$ A fentebbiekből következően az előállító üzem jogosult volt a szabadforgalomba bocsátás időpontjáig az általa elóállított, tárolt alkoholterméket adómentesen tárolni, hasonlóképp, mint a mai szabályozásban az adóraktár engedélyese.

Az ásványolajtermékek előállítója, a "finomítógyáros" (mai szóhasználattal élve: a kőolajfinomító, vagyis: ásványolaj adóraktár engedélyes) volt. A finomítótógyáros a mai adóraktár engedélyeshez hasonló módon szigorú bejelentési, engedélyezési, nyilvántartás-vezetési, adatszolgáltatási és könyvvezetési kötelezettséggel bírt.

\subsection{Ellenőrzés, hatósági felügyelet, garanciális feltételek}

$\mathrm{Az}$ alkoholtermékek vonatkozásában nyílt városokban az adók beszedése a királyi pénzügyigazgatóság feladata volt. A pénzügyi hatóságnak, az adószedésre jogosultnak lehetősége volt, hogy bármikor jövedéki ellenőrzést tartson. 1924-től kötelezővé tették a szeszmérő gépek alkalmazását. Ettől a pillanattól kezdődően a

\footnotetext{
${ }^{492}$ TAKÁCS: i. m. p. 168.

${ }^{493}$ TAKÁCS: i. m. p. 173.

${ }^{494}$ TAKÁCS: i. m. p. 174.

${ }^{495}$ TAKÁCS: i. m. p. 166.

${ }^{496}$ A különböző szeszfőzde típusok részletes leírását lásd bővebben uo.: pp. 170-171.
} 
regisztrált mérőszerkezet nélküli berendezésen végzett lepárlás zugtevékenységnek minősült. ${ }^{497}$

„A vállalkozó a felügyelettel megbizott közegeknek az üzleti helyiségben vagy hozzá közel fekvő épületben lakást és irodai szobát tartozik átengedni A lakásért fizetendö bért a pénzügyigazgatóság a vállalkozóval kötendö egyezség útján állapítja meg, és ha egyezség nem jönne létre, akkor a lakásbért az elsöfokú közigazgatási hatóság határozza meg. A pénzügyi közegek az üzleti helyiségekbe szabadon beléphetnek és az üzlet folyama alatt éjjel is bennük tartózkodhatnak. " ${ }^{498}$ Mindemellett, a finomító területéről kiszállítani kívántásványolajterméket - annak megkezdése előtt legalább hat órával - a pénzügyi igazgatósághoz két példányban, írásban tett bejelentést követően lehetett csupán kitárolni. A szigorú hatósági felügyelet további elemei közé tartozott továbbá, hogy az ásványolajtermék kiszállítása a kőolaj finomító telephelyéről csak nappal, a pénzügyi igazgatóság által megjelölt útvonalon történhetett. Minden egyes finomító üzem körül a pénzügyi igazgatóság úgynevezett ellenőrzési kerületet létesített. Ezen a zónán belül az üzlethelyiségből/telephelyből kijövő összes szállítmányt megjelölési kötelezettség terhelte: ez azt jelentette a gyakorlatban, hogy minden egyes szállítmányt úgynevezett eladási bárcával (igazolvánnyal, tanúsítvánnyal) láttak el. Ezen felül a 20 kg-ot meghaladó súlyú szállítmányok vonatkozásában a pénzügyi közeg felszólítására a szállítmány birtokosa köteles volt igazolni a szállított termék származását, eredetét, adózott voltát. A szoros hatósági felügyeletet előíró szabályok garantálták azt, hogy a hatóság tudta nélkül ne lehessen előállítani, szállítani, értékesíteni ásványolajterméket. További garanciális feltétel volt az is, hogy addig, amíg nem fizették meg az elöállított jövedéki termék után az adót, addig azt nem lehetett a finomító területéről kitárolni. Az adófizetést az garantálta, hogy az azt igazoló tényt a kitárolandó termékhez csatolt bárcával kellett igazolni. ${ }^{499}$

\subsection{Nyilvántartás vezetési kötelezettség}

Minden finomító üzemben úgynevezett eladási lajstromot kellett vezetni, melyben fel kellett tüntetni az eladott termék mennyiségi, minőségi adatait, továbbá a vevőre vonatkozó legfontosabb adatokat is (név, lakcím...stb.) Mindemellett a listán az eladás pontos idejét (év, hó, nap, óra, perc) is szerepeltetni kellett. Azok a kereskedők, akik ásványolajtermékek értékesítésével foglalkoztak, szintén a fentebb vázolt nyilvántartás vezetési kötelezettséggel bírtak.

\section{4. Összegzés}

Összegzésként megállapítható, hogy a dohányjövedék a középkortól napjainkig jelentős fejlődésen ment keresztül. A magyar szabályozás gyökerei - hazánk történelmi és földrajzi adottságai okán - az osztrák szabályozáson alapulnak, abból fejlődtek ki. „Tisztán” hazai szabályozásról éppen ezért csupán a kiegyezést követően beszélhetünk. A XIX. század utolsó harmadától a szocialista tervgazdálkodás megjelenéséig már igencsak fejlett, a mai szabályozás alapjait, jogintézményeit magában foglaló, szerteágazó jogi szabályozás jellemzi a dohányjövedéki szabályanyagot: számos, a mai jövedéki szabályozáshoz hasonló, az adott esetben azzal szinte teljes mértékben

\footnotetext{
${ }^{497}$ SólYOM Lajos: Pálinkafözés Kézikönyv kisüzemek számára. Mezőgazdasági Kiadó, Budapest, 1986. p. 18.

${ }^{498}$ EXNER: i. m. p. 374.

${ }^{499}$ EXNER: i. m. p. 374.
} 
megegyező intézkedést és jogintézményt találhatunk. Ilyenek voltak például az adófelfüggesztés („,feltételes adómentesség”) intézménye (a dohánytermék kiviteléhez, behozatalához és raktározási tevékenységéhez kapcsolódóan), vagy például az adómentesség és az adóvisszatérítés esetkörének szabályozása, továbbá az adóalany nyilvántartás vezetési és elszámolási („leszámolási”) kötelezettségének részletes szabályozása, valamint a jövedéki ellenőrzés fogalmának megjelenése és az ehhez kapcsolódó pénzügyi hatósági eljárás. Ezen felül megjelent a ma is ismert adóalanyok közül az adóraktár („szabad raktár”); az adójegy (banderoll) alkalmazásának kötelezettsége; a jövedéki biztosíték jogintézménye; a halasztott adófizetés lehetősége; a rendkívül szigorú szankciórendszer, illetve az objektív felelősség jogintézménye is.

A dohány jövedékisége teljes egyedáruságot jelentett, vagyis azt, hogy mind a nyers dohány, mind pedig a dohánygyártmányok felett kizárólagos rendelkezési jog illette meg az államot. Ezen kizárólagos jog folytán senkinek nem volt szabad az illetékes hatóság engedélye nélkül dohányt termelni, dohányt tiltott módon készíteni, felhasználni, vagy forgalomba hozni, illetve dohányt bármely célra - akár csak átszállítás végett is - külföldről behozni. A két világháborút követő évtizedekben a szocialista tervutasításos rendszernek betudhatóan - hasonlóan az alkohol és az ásványolaj szabályozásához - ideiglenesen eltünt a dohányjövedék, és úgy általában a jövedéki adó. A rendszerváltást megelőző években fogyasztási adó terhelte az egykori jövedéki termékeket, majd a rendszerváltást követő jogi szabályozás egészen hazánk 2004. május 1-i uniós csatlakozásáig fokozatosan átvette és beépítette szabályanyagába az Európai Unió jövedéki irányelveit, jogintézményeit, adóztatási szabályait. Az uniós szabályanyag azonban a 19. századi szabályozással szerves összefüggést mutat.

A modern kor jövedéki szabályozásának legfőbb kritériumait, alapjait - amely a jövedéki termékek előállításának, behozatalának szigorú állami kontrollját, valamint a szabadforgalomba hozatalához kapcsolódó adófizetési kötelezettségét jelenti, már több, mint 100 évvel annak gyakorlati megvalósulása előtt tisztán vizionálta Kautz Gyula. Elöremutató gondolatai, meglátásai a dohányjövedék fejlődése során (is) a gyakorlati élet részévé váltak.

„...maga a tulajdonképpeni dohány monopol-rendszer, mely a kizáró nyerstermelést, a monopolistikai átalakitást (gyártás utjáni készittetést), meg az adót tulajdonkép megállapitó egyedárui forgalmazást foglalja magában (...) nemzetgazdasági tekintetben is sok országra nézve (...) életfontosságú ipar-és termelési ág monopolistikai kezelés által módfelett lankasztik: (...) egy más s ésszerübb megadóztatási módszer felállítása, magának az államnak éppúgy mint a nemzetgazdaságnak érdekében fekszik. - E módozat tekintetében (...) egy a dohányfogyasztásra, azután a dohány-elóállitásra kivetendö adó volna foganatbaveendő..." 500

Amint az idézetböl is kiolvasható, a XIX. századi szabályozás - amely a termelés engedélyeztetését és dohány-beszolgáltatási kötelezettséget is magában foglalta - oly' mértékben korlátozta a dohányipari-szektor fejlődéséi lehetőségeit, hogy a rendszerváltást követően az állam egyedárusítási joga a korábbi szabályozáshoz mérten már nem a termelésre és beszolgáltatási kötelezettségre fókuszál, hanem a dohánygyártmány előállításának és forgalmazásának szigorú kontrolljára, illetve a dohánygyártmányok fogyasztásának magas szintủ adóztatására.

$\mathrm{Az}$ alkoholtermékek jövedéki szabályozása a középkortól napjainkig szintén jelentős fejlődésen ment keresztül. A XIX. században már ennél a jövedéki

\footnotetext{
${ }^{500}$ KAUTZ Gyula: A nemzetgazdaság és pénzügytan, tekintettel a gyakorlati iparéletre és a fensöbb tanulmány szükségeire. Pest, 1863. p. 559.
} 
termékkörnél is kifejezetten fejlett, a mai szabályozás alapjait, jogintézményeit tartalmazó jogi szabályozás a jellemzö, ugyanis a korabeli szabályanyag már tartalmazza az engedélyezés, a jövedéki ellenőrzés, és a hatósági felügyelet intézményeit, továbbá a jövedéki biztosíték, mint garanciális elem is megjelenik a szabályanyagban. Mint láthattuk, a XIX. század végére a jövedéki szabályozás tovább terjedt és már az alkoholtermék nagykereskedelmét is érintette. A XX. század első harmadára már a szeszegyedáruság teljes mértékben kiteljesedett: lényegében az ország területére behozott, vagy ott előállított valamennyi alkoholtermék az állam kizárólagos rendelkezése alatt állt mindaddig, amíg azt a szesz egyedárusági igazgatóság akár a felhasználási cél meghatározásával, akár anélkül szabadforgalomba nem bocsátotta. Mindemellett fokozatosan megjelentek a mai jövedéki szabályozás újabb elemei is: az adómentes felhasználás és az adóraktári tevékenység, továbbá a denaturálási eljárás előzményei.

Az ásványolajtermékek felhasználásának elterjedésével összefüggésben is megállapítható, hogy a 19. századtól a mai szabályanyagra rendkívüli módon hasonlító jogintézmények jelentek meg. Ilyenek voltak például az adóraktár („,finomító gyáros”) a rendkívül szigorú tárgyi, személyi, garanciális feltételeket tartalmazó engedélyesi eljárás, az adóköteles és az adómentes tevékenységi körök elhatárolása, továbbá a hatósági felügyelet részletekbe menő, kidogozott módszerei, mint például a bejelentési kötelezettség, a pénzügyőri jelenlét, a szigorú elszámolási rend. Hangsúlyos különbségként mutatkozik meg a mai szabályozáshoz képest hogy a 19. században az adóköteles ásványolajtermékek körébe a világítási célú felhasználáshoz kapcsolódó termékek tartoztak (petróleum lámpa), addig a 20. századi (és mai) szabályozás szerint az adóköteles tevékenységi körbe elsősorban a belső égésű motorok üzemanyag célú felhasználási köréhez tartozó ásványolajtermékek kapcsolódnak. Fontos kihangsúlyozni a törvénysértésekhez kapcsolódó szigorú - maihoz hasonló - szankciórendszer megjelenését is. E tekintetben lényeges különbség azonban, hogy egykor még kihágásoknak minősültek a jogsértések, míg ma jövedéki (közigazgatási-adóigazgatási) törvénysértésnek, illetve bizonyos elkövetési értékhatár fölött ezzel párhuzamosan manapság büntetőjogi szankciók alkalmazására is számíthat az elkövető.

Fentebbiekre tekintettel összességében megállapítható, hogy gyakorlatilag a mai jövedéki jogintézmények többsége már a 19. század végére, 20 század elejére megjelent a korabeli szabályozásban. Mindemellett a szabályozás részletessége, kifinomultsága, alapossága is a mai szabályanyagra emlékeztet, így nyugodtan megállapíthatjuk, hogy a szabályozás lényegi elemeit tekintve nincs új a nap alatt. legfeljebb a technológiai megoldások (digitalizáció, informatikai rendszerek, automatizmusok) bevezetése az, ami mássá, eltérővé teszi azt.

\section{Felhasznált irodalom}

[1] ÁldÁSSY Antal - ÁBRÁNYI Kornél - ACZÉL Károly - ÁGOSTON József (szerk.): Pallas nagy lexikona. Budapest, Pallas Irodalmi és Nyomdai Részvénytársaság, 1895.

[2] ARDAI Ignácz - EXNER Kornél: Magyar jövedéki büntetöjog. Nyomtatott Márkus Samu nyomdájában. Budapest, 1896.

[3] EXNER Kornél: Magyar Pénzügyi Jog. Atheneum Irodai és Nyomdaipari Részvénytársulat kiadása, Budapest, 1910.

[4] KaUTz Gyula: Nemzetgazdaság és Pénzügytan. Kiadja: Heckenast Gusztáv Pest, 1863. 
[5] KARVASSY Ágoston: Politikai tudományok. III. kötet: A fináncztudomány. Győr, 1844.

[6] MAGASVÁRI Adrienn: Vám-és adószedők a magyar pénzügyi igazgatásban az államalapitástól a kiegyezésig. RENDVÉDELEM TÖRTÉNETI FÜZETEK, 25. évf, 43-44-45-46. sz., 2016.

[7] MARISKA Vilmos: Pénzügyi jog. VI. kiadás, 1896. p. 812.

[8] Pallas Nagylexikona https://www.arcanum.hu/hu/online-kiadvanyok/Lexikonoka-pallas-nagy-lexikona-2/h-B866/italmeresi-jovedek-D925/(Letöltés ideje: 2019. augusztus 17.)

[9] PAPP Antal: Dohányjövedék. Toldy Lajos Könyvkereskedö Bizománya. Budapest, 1907.

[10] SimOn IstVÁn (szerk.): Pénzügyi jog II. Osiris Kiadó, Budapest, 2012.

[11] SIMON Zoltán - POZSGAI Zoltán - KIS Judit - Boros Sándor: Jövedéki alapok I. VIVA Média Bp. 2006.

[12] SóLYOM Lajos: Pálinkafözés Kézikönyv kisüzemek számára. Mezőgazdasági Kiadó, Budapest, 1986.

[13] SzABÓ Andrea.: A pénzügyi igazgatás szervezete és képzési rendszere a kiegyezéstöl az I. világháború végéig. In: CZENE-POLGÁR ViktóriaZsÁMBOKINÉ FICSKOVSZKY Ágnes (szerk.): Mérföldkövek az adó- és vámigazgatás történetéböl. Magyar Rendészettudományi Társaság Vám és Pénzügyőri Tagozata. Budapest, 2017. pp. 124-137.

[14] SzABÓ Andrea: A pénzügyi igazgatás szervezeti keretei egykor és most a rendészeti feladatok tükrében. In: GAÁL Gyula - Hautzinger Zoltán (szerk.): Szent Lászlótól a modernkori magyar rendészettudományig. Pécs, 2017. pp. 351-356.

[15] Dohánymúzeum. Forrás: http://dohanymuzeum.hu/magyar-kiralyidohanyjovedek-tortenete Letöltés ideje: 2016. június 20.

[16] 1842. harmincad hivatali utasítás 519. §

[17] 1878. évi V. törvénycikk a magyar büntetőtörvénykönyv a büntettekről és a vétségekröl

[18] 1883. XLIV. törvénycikk a közadók kezeléséről

Lektorálta: Sallai János Prof. Dr. tanszékvezető egyetemi tanár

Nemzeti Közszolgálati Egyetem Rendészettudományi Kar

Rendészettörténeti Tanszék

sallai.janos@uni-nke.hu 